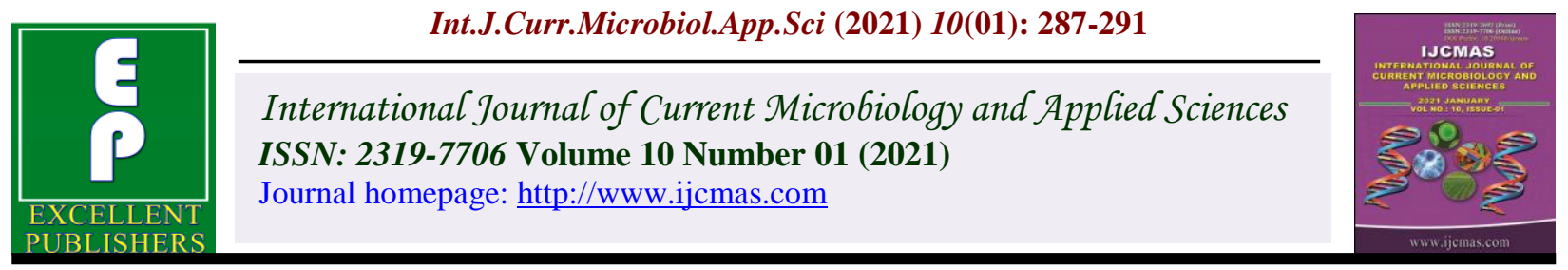

Original Research Article

https://doi.org/10.20546/ijcmas.2021.1001.035

\title{
Effect of Planting Dates on Growth and Yield of Pearl Millet (Pennisetum glaucum L.)
}

\author{
H. N. Kanjiya ${ }^{1^{*}}$, M. C. Chopada ${ }^{1}$, D. R. Vaghasiya ${ }^{1}$ and A. V. Savaliya ${ }^{2}$ \\ ${ }^{1}$ Agrometeorology Cell, Department of Agronomy, JAU, Junagadh, Gujarat, India \\ ${ }^{2}$ Subject Matter Specialist (Agromet) Krishi Vigyan Kendra, JAU, Jamnagar, Gujarat, India \\ *Corresponding author
}

\section{A B S T R A C T}

Keywords

Emergence,

Pearl millet,

Phenological, Yield

Article Info

Accepted:

04 December 2020

Available Online:

10 January 2021
An experiment was conducted to study the different dates of planting in pearl millet at the Instructional Farm, Department of Agronomy, Junagadh Agricultural University, Junagadh, Gujarat, India during the Summer season of year 2019. The objective of the study was to find out the effect of different dates of sowing on the yield of pearl millet. There were four planting dates viz., 25 $5^{\text {th }}$ January, $5^{\text {th }}$ February, $15^{\text {th }}$ February and $25^{\text {th }}$ February with three $c v s$. GHB-538, GHB-558 and GHB-732 variety. The experiment was laid out in Split Plot Design with three replications.

\section{Introduction}

Pearl millet (Pennisetum glaucum L.) is one of the most important millet crop grown in India. In the world, it's ranks sixth followed by rice, wheat, corn, barley and sorghum. However, in India, it is fourth most important cereal crop after rice, wheat and sorghum. Pearl millet Belongs to family Poaceae and genus Pennisetum. Pearl millet originated in central tropical Africa and widely distributed in the drier tropics and India. India is the largest producer of pearl millet in the world. In India major producing states are Rajasthan (46\%), Maharashtra (19\%), Gujarat (11\%), Uttar Pradesh (8\%) and Haryana (6 \%), which share about 90 per cent of total pearl millet production. Pearl millet occupies an area of 7.12 million hectares with a production of 8.06 million tonnes and productivity of $1132 \mathrm{~kg} / \mathrm{ha}$ in the country. While in Gujarat, Total grown area 4.31 lakh hectares with a total production of 9.31 lakh tonnes and productivity of $2158 \mathrm{~kg} / \mathrm{ha}$.(Anon. 2017).Nutritionally, the pearl millet grains are rich source of protein $(9-15 \%)$, fat $(5 \%)$, carbohydrates $(67 \%)$, mineral matters $(2-7$ $\%)$, high energy value (>360 Kcal/100g) and high $\mathrm{Fe}, \mathrm{Zn}$ and $\mathrm{Ca}$ compared to other cereals. Thus, it is the cheapest source not only energy and protein but also for micronutrients such as $\mathrm{Fe}$ and $\mathrm{Zn}$. It is rich in vitamin-A and $\mathrm{B}$, 
thiamine and riboflavin content and imparts substantial energy to the body with easy digestibility. It is gluten free and has also low glycine index. Apart from grain, dry fodder is an important secondary product in low resource agriculture for animal feed and fuel.

\section{Materials and Methods}

The field experiment was conducted during summer season of year 2019 at Instructional Farm, Department of Agronomy, JAU, Junagadh (Gujarat). Geographically the experimental site was situated at $21.51^{\circ} \mathrm{N}$ latitude and $70.55^{\circ} \mathrm{E}$ longitude at an altitude of $83 \mathrm{~m}$ above mean sea level. The experiment was laid out in split plot design, consisting 36 treatment combinations comprised of four sowing dates were $25^{\text {th }}$ January $\left(D_{1}\right), 5^{\text {th }}$ February $\left(D_{2}\right), 15^{\text {th }}$ February $\left(D_{3}\right)$ and $25^{\text {th }}$ February $\left(D_{4}\right)$ and three varieties were GHB-538 $\left(\mathrm{V}_{1}\right)$, GHB-558 $\left(\mathrm{V}_{2}\right)$ and GHB$732\left(\mathrm{~V}_{3}\right)$ with three replications.

After preparation of the field, the experiment was laid down. The recommended dose of nitrogen (120 kg N/ha) and phosphorus $(60 \mathrm{~kg}$ $\mathrm{P}_{2} \mathrm{O}_{5} / \mathrm{ha}$ ) were applied. Full dose of phosphorus and half dose of nitrogen were applied at the time of sowing and the remaining half dose of nitrogen was applied 25-30 days after sowing as top dressing. The source of nitrogen and phosphorus were Urea $(46 \% \mathrm{~N})$ and Diammonium phosphate (46\% $\mathrm{P}_{2} \mathrm{O}_{5}$ and $18 \% \mathrm{~N}$ ), respectively. The pearl millet crop was sown as per treatments with $45 \mathrm{~cm} \times 10 \mathrm{~cm}$ apart using seed rate of 3.75 $\mathrm{kg} / \mathrm{ha}$. Shallow furrows were opened and seeds were sown manually at the depth of 3 $\mathrm{cm}$. Gap filling was done in a few plots as required for uniform plant population. Thinning of extra seedlings was done 12 days after sowing to maintain $10 \mathrm{~cm}$ plant to plant distance. All the sown treatments of pearl millet crop irrigated with 7 to 10 days interval. The crop was maintained weed free by hand weeding twice at 20 and 40 days after sowing. Crop was harvested when majority of leaves (nearly $80 \%$ ) in plants senesced and earhead turned brownish in colour. The crop from net plot area was harvested plot wise separately. The harvested plants were handled vertically by keeping lower portion of plants downward to avoid the possible losses due to shattering.

Observations of the yield and yield attributes such as germination percentage, plant height at maturity $(\mathrm{cm})$, number of total tillers per plant, number of effective tillers per plant, length of earhead, diameter of earhead, grain yield $(\mathrm{kg} / \mathrm{ha})$, stover yield $(\mathrm{kg} / \mathrm{ha})$, harvest index and test weight were taken. Five plants were randomly selected and tagged in each of the experimental plots for studying individual plant characters. The data collected for various growth and yield attributes of pearl millet will be subjected to statistical analysis of variance techniques as described by Panse and Sukhatme (1985).

\section{Results and Discussion}

The yield and yield attributes derived from different dates of sowing and varieties were analyzed statistically by using split plot design and the results are presented in Table 1.

The results revealed that all the yield attributing characters of varieties were mostly significantly affected by the dates of sowing.

\section{Germination (\%)}

The germination was significantly affected by sowing dates. The maximum germination (90.89 \%) was observed in third date of sowing $\left(\mathrm{D}_{3}-15^{\text {th }}\right.$ February) and minimum (79.72\%) was observed in first date of sowing $\left(\mathrm{D}_{1}-25^{\text {th }}\right.$ January). Among the varieties, maximum germination $(89.71 \%)$ 
was observed in GHB 732 variety $\left(\mathrm{V}_{3}\right)$ and minimum germination $(82.15 \%)$ was observed in GHB 538 variety $\left(\mathrm{V}_{1}\right)$.

\section{Plant height at maturity $(\mathrm{cm})$}

The plant height was significantly affected by sowing dates. The maximum plant height $(187.45 \mathrm{~cm})$ was observed in third date of sowing $\left(\mathrm{D}_{3}-15^{\text {th }}\right.$ February). The minimum plant height $(155.51 \mathrm{~cm})$ was recorded in first date of sowing $\left(\mathrm{D}_{1}-25^{\text {th }}\right.$ January). Among the varieties, maximum plant height $(190.80 \mathrm{~cm})$ was observed in GHB 558 variety $\left(\mathrm{V}_{2}\right)$ and minimum plant height $(150.72 \mathrm{~cm})$ was observed in GHB 538 variety $\left(\mathrm{V}_{1}\right)$.

\section{Number of total tillers per plant}

The number of total tillers per plant was significantly affected by sowing dates. The maximum number of total tillers per plant (6.43) was observed in third date of sowing $\left(\mathrm{D}_{3}-15^{\text {th }}\right.$ February). While minimum number of total tillers per plant i.e. 5.16 was recorded in first date of sowing ( $D_{1}-25^{\text {th }}$ January). Among the varieties, maximum number of total tillers per plant (6.04) was observed in GHB 732 variety $\left(V_{3}\right)$ and minimum number of total tillers per plant (5.39) was observed in GHB 538 variety $\left(\mathrm{V}_{1}\right)$.

\section{Number of effective tillers per plant}

The number of effective tillers per plant was significantly affected by sowing dates. The maximum number of effective tillers per plant (6.43) was observed in third date of sowing $\left(\mathrm{D}_{3^{-}}-15^{\text {th }}\right.$ February) and minimum effective tillers per plant (3.86) were recorded in first date of sowing $\left(\mathrm{D}_{1}-25^{\text {th }}\right.$ January). Similarly, number of effective tillers per plant was significantly affected by varieties. Maximum number of effective tillers per plant (4.32) was observed in GHB 732 variety $\left(\mathrm{V}_{3}\right)$ and minimum number of effective tillers per plant
(3.98) was observed in GHB 538 variety $\left(V_{1}\right)$.

\section{Length of earhead (cm)}

The length of earhead was also significantly affected by sowing dates. The maximum length of earhead $(24.31 \mathrm{~cm})$ was observed in third date of sowing $\left(\mathrm{D}_{3^{-}}-15^{\text {th }}\right.$ February) and minimum length of earhead $(21.22 \mathrm{~cm})$ was recorded in first date of sowing $\left(D_{1}-25^{\text {th }}\right.$ January).

Length of earhead was significantly affected by varieties. Maximum length of earhead (23.95) was observed in GHB 732 variety $\left(\mathrm{V}_{3}\right)$ and minimum length of earhead (21.83) was observed in GHB 538 variety $\left(\mathrm{V}_{1}\right)$.

\section{Diameter of earhead $(\mathrm{cm})$}

The diameter of earhead was significantly affected by sowing dates. The maximum diameter of earhead $(4.02 \mathrm{~cm})$ was observed in third date of sowing ( $\mathrm{D}_{3}-15^{\text {th }}$ February). Then, followed by $(3.78 \mathrm{~cm})$ in fourth date of sowing $\left(\mathrm{D}_{4^{-}} 25^{\text {th }}\right.$ February). Diameter of earhead was also significantly affected by varieties. Maximum diameter of earhead (3.60) was observed in GHB 732 variety $\left(V_{3}\right)$ and minimum diameter of earhead (3.30) was observed in GHB 538 variety $\left(\mathrm{V}_{1}\right)$.

\section{Grain yield (kg/ha)}

The grain yield was significantly affected by sowing dates. The maximum grain yield (4613 kg/ha) was observed in third date of sowing $\left(\mathrm{D}_{3^{-}} 15^{\text {th }}\right.$ February) and minimum grain yield $(3494 \mathrm{~kg} / \mathrm{ha})$ recorded in first date of sowing $\left(\mathrm{D}_{1^{-}} \quad 25^{\text {th }}\right.$ January).Similarly, maximum grain yield (4741 kg/ha) was observed in GHB 732 variety $\left(\mathrm{V}_{3}\right)$ and minimum grain yield (3587 kg/ha) was observed in GHB 538 variety $\left(\mathrm{V}_{1}\right)$. 
Table.1 Effect of sowing dates on yield and yield attributes of cultivars

\begin{tabular}{|c|c|c|c|c|c|c|c|c|c|c|}
\hline Treatment & $\begin{array}{c}\text { Germination } \\
(\%)\end{array}$ & $\begin{array}{c}\text { Plant } \\
\text { height at } \\
\text { maturity } \\
\text { (cm) }\end{array}$ & $\begin{array}{c}\text { Number } \\
\text { of total } \\
\text { tillers } \\
\text { per plant }\end{array}$ & $\begin{array}{c}\text { Number } \\
\text { of } \\
\text { effective } \\
\text { tillers per } \\
\text { plant }\end{array}$ & $\begin{array}{l}\text { Length } \\
\text { of } \\
\text { earhead } \\
\text { (cm) }\end{array}$ & $\begin{array}{c}\text { Diameter } \\
\text { of } \\
\text { earhead } \\
(\mathrm{cm})\end{array}$ & $\begin{array}{l}\text { Grain } \\
\text { yield } \\
\text { (kg/ha) }\end{array}$ & $\begin{array}{c}\text { Stover } \\
\text { yield } \\
\text { (kg/ha) }\end{array}$ & $\begin{array}{c}\text { Harvest } \\
\text { index } \\
(\%)\end{array}$ & $\begin{array}{c}\text { Test } \\
\text { weight } \\
\text { (gm) }\end{array}$ \\
\hline $\mathbf{D}_{1}$ & 79.72 & 155.51 & 5.16 & 3.86 & 21.22 & 2.93 & 3494 & 6313 & 35.66 & 8.68 \\
\hline $\mathbf{D}_{2}$ & 85.00 & 170.20 & 5.52 & 4.02 & 22.81 & 3.06 & 3950 & 6932 & 36.01 & 9.12 \\
\hline $\mathbf{D}_{3}$ & 90.89 & 187.45 & 6.43 & 4.45 & 24.31 & 4.02 & 4613 & 7492 & 38.00 & 9.81 \\
\hline $\mathbf{D}_{4}$ & 88.00 & 180.60 & 5.72 & 4.34 & 23.51 & 3.78 & 4282 & 7263 & 36.97 & 9.53 \\
\hline S.Em. \pm & 2.15 & 4.78 & 0.20 & 0.13 & 0.54 & 0.10 & 181.22 & 234.35 & 1.49 & 0.22 \\
\hline C.D. at $5 \%$ & 7.45 & 16.55 & 0.69 & 0.44 & 1.87 & 0.33 & 627.11 & 810.94 & NS & 0.76 \\
\hline C.V. \% & 7.52 & 8.27 & 10.52 & 9.06 & 7.04 & 8.33 & 13.31 & 10.04 & 12.16 & 7.10 \\
\hline $\mathbf{V}_{1}$ & 82.15 & 150.72 & 5.39 & 3.98 & 21.83 & 3.30 & 3587 & 6516 & 35.50 & 8.80 \\
\hline $\mathbf{V}_{2}$ & 85.85 & 190.80 & 5.69 & 4.20 & 23.10 & 3.45 & 3925 & 6948 & 36.17 & 9.42 \\
\hline $\mathbf{V}_{3}$ & 89.71 & 178.81 & 6.04 & 4.32 & 23.95 & 3.60 & 4741 & 7535 & 38.31 & 9.64 \\
\hline S.Em. \pm & 1.75 & 3.95 & 0.17 & 0.09 & 0.46 & 0.07 & 147.81 & 202.54 & 1.09 & 0.19 \\
\hline C.D. at $5 \%$ & 5.24 & 11.85 & 0.50 & 0.26 & 1.39 & 0.21 & 443.14 & 607.20 & NS & 0.56 \\
\hline C.V. \% & 7.04 & 7.89 & 10.06 & 7.15 & 7.01 & 7.08 & 12.54 & 10.02 & 10.29 & 7.01 \\
\hline \multicolumn{11}{|c|}{ Interaction (D X V) } \\
\hline S.Em. \pm & 3.49 & 7.91 & 0.33 & 0.17 & 0.93 & 0.14 & 295.62 & 405.07 & 2.18 & 0.38 \\
\hline C.D. at $5 \%$ & NS & NS & NS & NS & NS & NS & NS & NS & NS & NS \\
\hline
\end{tabular}




\section{Stover yield (kg/ha)}

The Stover yield was significantly affected by sowing dates. The maximum stover yield $(7492 \mathrm{~kg} / \mathrm{ha})$ was observed in third date of sowing $\left(\mathrm{D}_{3^{-}}-15^{\text {th }}\right.$ February). Whereas, minimum stover yield $(6313 \mathrm{~kg} / \mathrm{ha})$ recorded in first date of sowing $\left(\mathrm{D}_{1-}-25^{\text {th }}\right.$ January).Among the varieties, maximum stover yield $(7535 \mathrm{~kg} / \mathrm{ha})$ was observed in GHB 732 variety $\left(\mathrm{V}_{3}\right)$ and minimum stover yield $(6516 \mathrm{~kg} / \mathrm{ha})$ was observed in GHB 538 variety $\left(\mathrm{V}_{1}\right)$.

\section{Harvest index (\%)}

The harvest index was non-significantly affected by sowing dates as well as varieties. However maximum harvest index $(38.00 \%)$ was obtained from $D_{3}$ sown crop $\left(D_{3}-15^{\text {th }}\right.$ February). Whereas, minimum harvest index $(35.66 \%)$ was obtained from $\mathrm{D}_{1}$ sown crop $\left(\mathrm{D}_{1}-25^{\text {th }}\right.$ January $)$. Among the varieties, maximum harvest index (38.31\%) was observed in GHB 732 variety $\left(\mathrm{V}_{3}\right)$ and minimum harvest index $(35.50 \%)$ was observed in GHB 538 variety $\left(\mathrm{V}_{1}\right)$.

\section{Test weight (gm)}

The test weight was significantly affected by sowing dates. The maximum test weight $(9.81$ $\mathrm{gm})$ was observed in third date of sowing $\left(\mathrm{D}_{3^{-}}\right.$ $15^{\text {th }}$ February) and minimum test weight (8.68 $\mathrm{gm})$ observed in first date of sowing $\left(\mathrm{D}_{1}-25^{\text {th }}\right.$ January).Test weight was also significantly affected by varieties. Maximum test weight (9.64 gm) was observed in GHB 732 variety $\left(\mathrm{V}_{3}\right)$ and minimum test weight $(8.80 \mathrm{gm})$ was observed in GHB 538 variety $\left(\mathrm{V}_{1}\right)$.

In conclusion from the results of one-year field study during summer 2019, it was highlighted that among different dates of sowing and varieties, $\mathrm{D}_{3}\left(15^{\text {th }}\right.$ February $)$ and GHB 732 variety were found to be the most suitable for higher productivity of pearl millet under agro-climatic condition of Junagadh (Gujarat).

\section{References}

Anon. 2017. Gujarat Agricultural Statistics at a Glance 2016-17, Directorate of Agriculture, Gujarat State Gandhinagar. (http://agri.gujarat.gov. in).

Panse, V. G. and Sukhatme, P. V. 1985. Statistical methods for agricultural workers. $3^{\text {rd }}$ Revised edition. I.C.A.R., New Delhi.

\section{How to cite this article:}

Kanjiya, H. N., M. C. Chopada, D. R. Vaghasiya and Savaliya, A. V. 2021. Effect of Planting Dates on Growth and Yield of Pearl Millet (Pennisetum glaucum L.). Int.J.Curr.Microbiol.App.Sci. 10(01): 287-291. doi: https://doi.org/10.20546/ijcmas.2021.1001.035 